\title{
Effect of Spacing in Incidence and Severity of Garlic Rust (Puccinia Allii (Rudolphi.) and Bulb Yield and Related Traits of Garlic at Eastern Ethiopia
}

\author{
Worku Mengesha $^{1 *}$ and Azene Tesfaye ${ }^{2}$
}

${ }^{1}$ Department of Plant Sciences, Aksum University, Aksum, Ethiopia

${ }^{2}$ Biodiversity research Center, Arba Minh University, Arba Minch, Ethiopia

\begin{abstract}
Garlic rust is caused by Puccinia allii (Rudolphi) extremely hinder the productivity of Alliaceae species, especially garlic (Allium sativum). The disease has been found wherever garlics are cultivated and at present no system of control has been found that fully prevents the occurrence of the disease. A field experiment was conducted to determine the optimum planting density for abating garlic rust in order to maximize yield of garlic. The experiment was laid out in RCBD with three replications, garlic local cultivar (Chiro) and three levels of intra-row spacing (10 $\mathrm{cm}, 15 \mathrm{~cm}$ and $20 \mathrm{~cm}$ ) were included in the study. Disease incidence and severity, plant height, Bulb yield, bulb diameter, Days to maturity, Plant height, Total yield (t/ha), Bulb weight (gm), Bulb diameter, Number of cloves per bulb and Clove weight were analyzed using SAS software. The result of the study revealed that the spacing was varied significantly in disease incidence and severity and in aforementioned agronomic data. The maximum yield was observed from plot planted with $10 \mathrm{~cm}$ intra row spacing where was the minimum value of yield was recorded at plot planted with 20 intra row spacing. The results explained that increasing intra-row spacings from 10 to $20 \mathrm{~cm}$ decreased significantly $(P \leq 0.05)$ in disease incidence and severity simultaneously increased yield of garlic. Based on the results obtained, it could be concluded that spacing $10 \mathrm{~cm} \times 30 \mathrm{~cm}$ is optimal for better production of garlic under disease conditions.
\end{abstract}

Keywords: Allium sativum; Bulb yield; Puccinia allii; Spacing

\section{Introduction}

Garlic (Allium sativum L.), belongs to the family Alliaceae and is the second most widely used Allium next to onion [1]. In Ethiopia, the Alliums group (onion, garlic, and shallot) are important bulb crops produced for home consumption, spices, medicinal plant and as a source of income to many peasant farmers in many parts of the country as described by [2]. Garlic is one of the most important bulb vegetables, which is used as spice and flavoring agent for foods. It adds to taste of foods as well as it helps to make them digestible. Garlic contains different essential minerals, vitamins and many other substances used for health of human beings. It is rich in sugar, protein, fat, calcium, potassium, phosphorous, sulfur, iodine fiber and silicon in addition to vitamins. It possesses high nutritive value. Furthermore, garlic has miracle pharmaceutical effects and used to cure an enormous disease including blood pressure and cholesterol, cancer, hepatoprotective, antihelmentics, antiinflammatory, antioxidant, antifungal and wound healing, asthma, arthritis, sciatica, lumbago, backache, bronchitis, chronic fever, tuberculosis, rhinitis, malaria, obstinate skin disease including leprosy, leucoderma, discoloration of the skin and itches, indigestion, colic pain, enlargement of spleen, piles, fistula, fracture of bone, gout, urinary diseases, diabetes, kidney stone, anemia, jaundice, epilepsy, cataract and night blindness as mentioned by (Azene and Mengesha) [3].

Despite its importance, the productivity of garlic across the globe especially in Ethiopia is generally low due to numerous and prominent production problems which encompass lack of proper planting material, inappropriate agronomic practices, absence of proper pest and disease management practices and marketing facilities, abiotic and biotic factors. Pinto, et al. [4] elucidated that Insects and fungi are the major pests of the plant across the globe among the fungal diseases, garlic rust is the most serious disease that prevalent worldwide and cause severe economic losses in onion and garlic crops as explicated by Perez et al. [5]. Similarly, Pinto, et al. [4] reported that garlic rust attacks the crop throughout its developmental stages since the developmental process is important in the progression of diseases. It is assumed that densely populated plants are ideal habitats for fungal development and transmission to the nearby plant since moisture is retained within the leaves, and it prevents direct sunshine as explained by [6]. Limited options are available due to wind dispersal nature of these pathogens.

Garlic rust is the serious disease of garlic in almost all garlic producing regions of Ethiopia and it decline the productivity of crop for the last many years as described by Tesfaye and Habtu [7].

A number of studies in various parts of the world have shown that garlic production can be improved through proper spacing. It has been reported by Mohammad et al. that plant spacing significantly increase number of cloves per bulb, bulb size, bulb weight and yield. Naruka and Dhaka [8] and Alam, et al. [9] indicated that garlic bulb yields increased significantly with increasing intra-row spacings. It is better to evaluate the effects of different plant spacing in the disease incidence and severity, and bulb yield and related traits of garlic. The most common garlic spacing in Ethiopia is $30 \mathrm{~cm}$ between rows and $10 \mathrm{~cm}$ between plants (EARODRCV, 2004). In Eastern Ethiopia, garlic rust occurs and distributed naturally. It extremely hinders the productivity of such nutraceutical plant. However, no research work has been done

${ }^{*}$ Corresponding author: Worku Mengesha, Department of Plant Sciences, Aksum University, Aksum, Ethiopia, E-mail: workumenge88@gmail.com

Received October 27, 2015; Accepted November 16, 2015; Published November 20, 2015

Citation: Mengesha W, Tesfaye A (2015) Effect of Spacing in Incidence and Severity of Garlic Rust (Puccinia Allii (Rudolphi.) and Bulb Yield and Related Traits of Garlic at Eastern Ethiopia. J Plant Pathol Microbiol 6: 314. doi:10.4172/21577471.1000314

Copyright: $(2015$ Mengesha W, et al. This is an open-access article distributed under the terms of the Creative Commons Attribution License, which permits unrestricted use, distribution, and reproduction in any medium, provided the original author and source are credited. 
Citation: Mengesha W, Tesfaye A (2015) Effect of Spacing in Incidence and Severity of Garlic Rust (Puccinia Allii (Rudolphi.) and Bulb Yield and Related Traits of Garlic at Eastern Ethiopia. J Plant Pathol Microbiol 6: 314. doi:10.4172/2157-7471.1000314

to determine the optimum spacing that minimizes disease incidence and severity in order to utilize the crop with its full potential.

Determining the relationship between yield losses and disease severity is an ideal method to identify effective and economical management methods to minimize garlic rust. Determine the optimal plant spacing is the best, easy and accuracy way to minimize such garlic rust simultaneously maximize yield of garlic especially in developing country and also this method enables community to utilize the plant with its full potential. Mohibullah [10] justified that by decreasing the plant population from 2 to 0.5 million ha $^{-1}, 10 \%$ decrease in rust severity and simultaneously increase garlic yield by $28 \%$. In a different spacing experiment conducted on onion, $75 \%$ decrease in plant population caused $20 \%$ reduction in downy mildew severity and $23 \%$ increase in onion yield. Therefore, the main focus of the present research was to determine the optimum planting density to control garlic rust in order to maximize garlic yield.

\section{Materials and Methods}

The study was conducted under rainfed conditions during the year 2012/13 main cropping season at Raree, Eastern Ethiopia. The experimental site is located within Haramaya University at $42^{\circ} 3^{\prime} \mathrm{E}$ longitude, $9^{\circ} 26^{\prime} \mathrm{N}$ latitude and at an altitude of 1980 m.a.s.l. The mean annual rainfall is $760 \mathrm{~mm}$. The mean maximum and minimum annual temperatures are 23.4 and $8.25^{\circ} \mathrm{C}$, respectively.

The experiment was conducted using one garlic local variety (Chiro), three types of planting densities (0.33, 0.23 and 0.16 million/ ha plants). Uniform sized cloves of garlic were used as seed (planting material). There were a total of 3 treatments comprising one garlic variety $\mathrm{X}$ three spacings treatments. Each plot consists of five rows of $2 \mathrm{~m}$ length with a distance of $0.3 \mathrm{~m}$ between rows. The space between plots and blocks was 1 and $1.5 \mathrm{~m}$, respectively. The treatments were arranged in a randomized complete block design (RCBD) with three replications.

\section{Disease assessment}

Disease incidence percentage (plants showing symptoms divided by total observation) was assessed from 10 randomly selected plants on the onset of the first symptom appearance and the assessment was carried out on weekly basis.

Disease severity was recorded and estimated in percentage of the leaf surface covered with lesions. It was assessed from all leaves of a plant and the average was recorded for the respective plant. Average severity of the 8 plants per plot was used for statistical analysis.

\section{Agronomic data recorded}

Data of yield and yield components and other agronomic parameters, were collected as follows.
1. Days to maturity: number of days taken from emergence to $75 \%$ leaf fall.

2. Plant height $(\mathrm{cm})$ : average height of 10 plants of each plot measured from ground level to the tip of the pseudo stem at maturity.

3. Total yield ( $t / h a)$ : yield estimated from the middle three rows of each plot after curing and transformed to tons per hectare.

4. Bulb weight (gm): average weight of 10 bulbs taken from each plot after curing.

5. Bulb diameter $(\mathrm{mm})$ : average diameter of 10 bulbs from each plot after curing using digital caliper.

6. Number of cloves per bulb: average number of cloves of 10 bulbs from each plot.

7. Clove weight (g): bulb weight divided by number of cloves per bulb.

\section{Data analysis}

Data on garlic rust severity from each assessment date, yield and yield components, and agronomic data were subjected to analysis of variance by using SAS computer software. Least significant difference (LSD) values at $(\alpha=0.05)$ were used to separate differences among treatment means.

\section{Results and Discussion}

\section{Garlic rust onset and intensity}

Garlic rust was first observed at 91 days after planting (DAP) and garlic rust assessment was started at 93 DAP. The disease first appeared on all plots simultaneously. The different types of spacing were significantly $(p \leq 0.05)$ different in terms of their respective reaction to the disease incidence. The highest average severity level of garlic rust was recorded from plot planted with $10 \mathrm{~cm}$ intra row spacing while, the lowest average disease severity level of garlic rust was observed from plot planted with 20 intra row spacing $\mathrm{cm}$ spacing (Table 1).

\section{Disease severity}

The different types of spacing create a significantly different ( $\mathrm{p} \leq$ 0.05 ) in their effects on disease severity (Table 1). Intra row spacing responded differently to garlic rust and high variation were existed between spacing (Figure 1).The maximum amount of disease severity (53.33\%) was observed at plot planted with $10 \mathrm{~cm}$ spacing, while the lowest amount of disease severity (26.67\%) was observed at plot planted with $20 \mathrm{~cm}$ spacing (Table 1). The result showed that increment of intra row spacing result in decrement of disease severity. This finding is in line with the findings of Darabi and Dehghani [11] who reported that disease severity increased when intra-row and inter-row spacing decreased from $13 \times 40 \mathrm{~cm}$ to $7 \times 10 \mathrm{~cm}$. This might be due to that as

\begin{tabular}{|c|c|c|c|c|c|c|c|c|c|}
\hline \multirow{2}{*}{$\begin{array}{c}\text { Spacing } \\
(\mathrm{Cm})\end{array}$} & \multicolumn{6}{|c|}{ Garlic rust severities at different days after planting } & \multicolumn{3}{|c|}{ Garlic rust incidences at different DAP } \\
\hline & 93 DAP & $100 \mathrm{DAP}$ & 107 DAP & 114 DAP & 121 DAP & $128 \mathrm{DAP}$ & $93 \mathrm{DAP}$ & $100 \mathrm{DAP}$ & $107 \mathrm{DAP}$ \\
\hline 10 & 5.42 & 17.83 & 28.07 & 33.72 & 40.80 & 53.33 & 34.90 & 67.50 & 100.00 \\
\hline 15 & 4.36 & 15.75 & 25.012 & 31.99 & 39.66 & 50.76 & 33.17 & 65.83 & 100.00 \\
\hline 20 & 2.94 & 13.43 & 21.63 & 30.88 & 36.18 & 48.47 & 26.67 & 59.50 & 87.50 \\
\hline CV (\%) & 15.63 & 21.20 & 17.86 & 8.13 & 6.68 & 5.72 & 19.80 & 13.88 & 2.10 \\
\hline SE $( \pm)$ & 0.21 & 1.24 & 2.03 & 1.06 & 1.20 & 2.04 & 1.35 & 3.39 & 1.02 \\
\hline LSD (5\%) & 0.49 & 2.48 & 3.33 & 1.96 & 1.94 & 2.18 & 4.68 & 6.67 & 1.39 \\
\hline
\end{tabular}

Table 1: Garlic rust severity and incidence on garlic under different spacing 


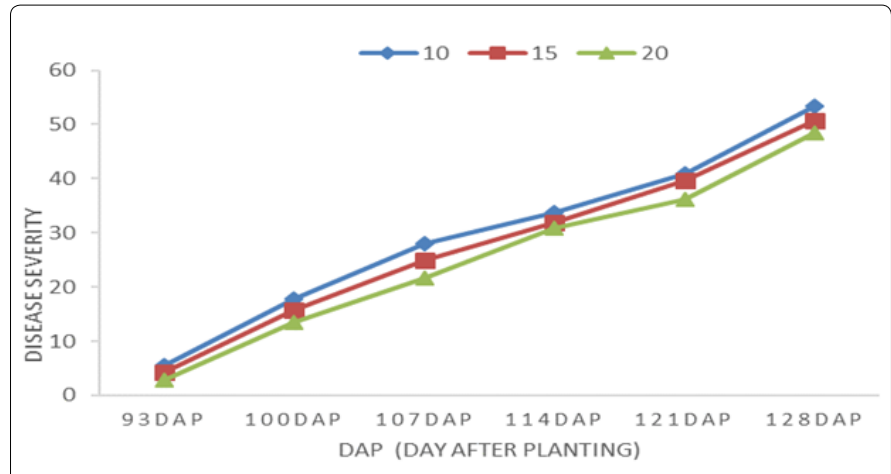

Figure 1: Disease progress under different spacing

the plant population increases the transmission of the rust to the next plant also increases.

\section{Effects of spacing on yield and related traits of garlic}

Total bulb yield: There was significant $(\mathrm{p}<0.05)$ difference in total bulb yield of garlic plots planted with different intra row spacing. The maximum bulb yield $(7.8 \mathrm{t} / \mathrm{ha})$ was obtained from plots planted with $10 \mathrm{~cm}$ intra row spacing whereas, the lowest value of average total bulb yield (4.85 t/ha) were achieved from plots planted with $20 \mathrm{~cm}$ intra row spacing (Table 2). The result explained that total bulb yield of the garlic was deceased as increment of intra row spacing. The result was in accordance with research results of [12] who reported that total bulb yield deceased due to increase of intra row spacing. Similarly, Darabi and Dehghani [11] total bulb yield deceased due to increase in the distance between rows and plants, but the mean weight of bulb and clove increased. Therefore, the highest total bulb yield and the lowest mean weight of bulb and clove were produced with spacing of $20 \times 7$ $\mathrm{cm}\left(714,285.71\right.$ plants $\left.\mathrm{ha}^{-1}\right)$. The plant densities which are considered as the most favorable for high bulb yields in garlic production range from 450,000 to 880,000 plants ha $^{-1}$ as illustrated by Karaye and Yakubu [13]; Abubakar et al [14] and Kilgori [12]. The increment of bulb yield at closer spacing might be ascribed to the increase in plant population per unit land area, while the decrease in bulb yield at wider intra-row spacing could be associated with decreased plant population per unit land area. It can thus be explained that the bulb yield per plant area depended not only on the performance of individual plants but also on the number of plants per unit area as confirmed in this study.

Bulb weight: There was significant $(\mathrm{p}<0.05)$ difference in bulb weight of garlic plots planted with different intra row spacing. The maximum bulb weight ( $31.52 \mathrm{~g}$ ) was obtained from plots planted with $20 \mathrm{~cm}$ in intra row spacing and the lowest values of bulb weight was recorded from plots planted with $10 \mathrm{~cm}$ intra row spacing $(27.44 \mathrm{~g})$ from $10 \mathrm{~cm}$ spacing between plants. The bulb weight $(28.21 \mathrm{~g})$ obtained from $15 \mathrm{~cm}$ spacing was not significantly different from bulb weight of plot planted with $10 \mathrm{~cm}$ intra row spacing (Table 2). The result justified that increment of intra row spacing increase bulb weight of the plant. This research finding is in line with the findings of Darabi and Dehghani [11] increasing the distance between rows and plants decreased the total bulb yield but increased the mean bulb and clove weights. Therefore, the highest total bulb yield and the lowest mean weights of bulb and clove were produced with spacing of $20 \times 7 \mathrm{~cm}$. On the contrary, Karaye and Yakubu [13] reported that decreasing the plant to plant distance from 20 to $10 \mathrm{~cm}$ decreased the yield from 9176.7 to $5263.3 \mathrm{~kg} / \mathrm{ha}$. This might be due to in the lowest spacing there might be nutrient competition as well as high disease severity.
Bulb diameter: There was significant $(\mathrm{p}<0.05)$ difference in bulb diameter of garlic plots planted with different intra row spacing. Intra row spacing created significant different on bulb diameter. The longest bulb diameter $(34.59 \mathrm{~mm})$ was obtained from plots planted with 20 $\mathrm{cm}$ intra row spacing while, the shortest bulb diameter $(30.44 \mathrm{~mm})$ of garlic was recorded from plot planted with $10 \mathrm{~cm}$ intra row spacing (Table 2). Bulb diameters obtained from plot planted with 10 and $15 \mathrm{~cm}$ intra row spacing did not show significant difference. Similar research results were reported by Jorind [6] there was no significant difference on bulb diameter with increment of intra-row spacing from 15 to $20 \mathrm{~cm}$ intra row spacing in 2011 dry season. This might be due to the lowest spacing that might intensified the nutrient competition and might resulted in high disease severity and, therefore, prominent to higher bulb diameter observed from 20 intra row spacing than both 15 and $10 \mathrm{~cm}$.

Clove weight and number of cloves per bulb: There was significant $(\mathrm{p}<0.05)$ difference in clove weight and number of clove of garlic plots planted with different intra row spacing (Table 2). The maximum clove weight $(1.74 \mathrm{~g})$ was obtained from plot planted with $20 \mathrm{~cm}$ intra row spacing whereas, the minimum value of clove weight $(1.53 \mathrm{~g})$ observed in plot planted with $10 \mathrm{~cm}$ intra row spacing (Table 2). The findings of this study indicated that bulb weight of garlic was significantly affected by spacing and Increasing of intra-row spacing from 10 to 20 $\mathrm{cm}$ significantly increased bulb weight. This finding is full agreement with research findings of Darabi and Dehghani [11]; Adejpe et al. [15] and Abubakar et al [14] who reported that increasing intra row spacing decreased the total bulb yield but increased the mean weights of bulbs and cloves. The reason for this might be due to the lowest spacing might increase nutrient competition as well as increase disease severity.

Days to maturity: There was no a significant statistical variation ( $p>0.05$ ) in days to maturity between the different spacings (Table 2). Hence this parameter is not affected by spacing.

Plant height: There was no a significant statistical variation ( $p>0.05$ ) in plat height between the different spacings (Table 2). Hence this parameter is not affected by spacing.

\section{Correlation among disease incidence, disease severity and yield and related traits of garlic}

Correlation analysis revealed that some of agronomic data of garlic significantly $(\mathrm{p} \leq 0.05)$ negatively correlate to weekly levels of garlic rust severities and total yield and yield related traits except with the number of cloves per bulb. Based on the coefficients of correlation (r) computed for the relationships between the disease and yield parameters, the garlic rust severity was strongly $(\mathrm{p} \leq 0.05)$ and negatively correlated with the total yield, bulb weight, bulb diameter and clove weight. Plant height had a non-significant negative relationship (Table 3 ). There was no significant $(\mathrm{p} \leq 0.05)$ correlation between number of cloves per bulb and plant height and garlic rust severities (Table 2). Yonas

\begin{tabular}{|c|c|c|c|c|c|}
\hline Spacing (cm) & $\begin{array}{c}\text { TY } \\
\text { (t/ha) }\end{array}$ & $\begin{array}{l}\text { BW } \\
\text { (g) }\end{array}$ & $\begin{array}{c}\text { BD } \\
(\mathrm{mm})\end{array}$ & $\begin{array}{l}\text { CW } \\
\text { (g) }\end{array}$ & $\begin{array}{c}\text { DM } \\
\text { (Days) }\end{array}$ \\
\hline 10 & 7.87 & 27.44 & 30.44 & 1.53 & 145.33 \\
\hline 15 & 6.38 & 28.21 & 32.00 & 1.62 & 145.27 \\
\hline 20 & 4.85 & 31.52 & 34.59 & 1.74 & 145.67 \\
\hline CV (\%) & 12.16 & 13.35 & 10.70 & 12.38 & 3.163 \\
\hline $\operatorname{SE}( \pm)$ & 0.3 & 1.37 & 1.26 & 0.08 & 0.678 \\
\hline LSD (5\%) & 0.73 & 3.75 & 3.34 & 0.19 & 3.44 \\
\hline
\end{tabular}

Table 2: Means of yield and yield related parameters on different garlic plant spacing. 
Citation: Mengesha W, Tesfaye A (2015) Effect of Spacing in Incidence and Severity of Garlic Rust (Puccinia Allii (Rudolphi.) and Bulb Yield and Related Traits of Garlic at Eastern Ethiopia. J Plant Pathol Microbiol 6: 314. doi:10.4172/2157-7471.1000314

\begin{tabular}{|c|c|c|c|c|c|c|c|}
\hline & PH & TY & BW & BD & CW & $\mathrm{CN}$ & DM \\
\hline idap93 & $-0.06879 n s$ & $0.12109 \mathrm{~ns}$ & $-0.12428 n s$ & $-0.10164 n s$ & $-0.07255 n s$ & $-0.30327^{*}$ & $-0.05767 n s$ \\
\hline idap100 & $-0.22843 n s$ & $-0.44630^{* *}$ & $-0.74102^{* *}$ & $-0.62780^{* *}$ & $-0.76378^{\star *}$ & $0.04709 \mathrm{~ns}$ & $-0.43629^{\star *}$ \\
\hline idap107 & $-0.07210 \mathrm{~ns}$ & $-0.43404^{* *}$ & $-0.77284^{* *}$ & $-0.56559^{* *}$ & $-0.74595^{\star \star}$ & $-0.00622 n s$ & $-0.43587^{\star *}$ \\
\hline sdap93 & $-0.04381 n s$ & $0.14759 \mathrm{~ns}$ & -0.53825 ** & $-0.60727^{\star *}$ & -0.51529 ** & $0.03283 \mathrm{~ns}$ & -0.33436 * \\
\hline sap100 & $-0.06086 n s$ & $-0.26987 n s$ & $-0.56614^{* *}$ & $-0.53795^{\star *}$ & $-0.63767^{* *}$ & $-0.03677 n s$ & $-0.18751 \mathrm{~ns}$ \\
\hline sdap107 & $0.00649 \mathrm{~ns}$ & $-0.40286^{\star *}$ & -0.69556 ** & $-0.67953^{* *}$ & $-0.76781^{\star *}$ & $0.03875 \mathrm{~ns}$ & $-0.27528 n s$ \\
\hline sdap114 & $-0.10723 n s$ & $-0.50125^{\star *}$ & $-0.81680^{* *}$ & $-0.66477^{\star *}$ & $-0.82069^{* *}$ & $0.05649 \mathrm{~ns}$ & $-0.46398^{* *}$ \\
\hline sdap121 & $-0.07776 n s$ & $-0.58145^{\star *}$ & $-0.86251^{* *}$ & $-0.77602^{* *}$ & -0.87099 ** & $0.11265 \mathrm{~ns}$ & $-0.49687^{\star *}$ \\
\hline sdap128 & $-0.00926 n s$ & $-0.60776^{* *}$ & $-0.88892^{* *}$ & $-0.81815^{\star *}$ & $-0.90913^{* *}$ & $0.18498 \mathrm{~ns}$ & $-0.50846^{* *}$ \\
\hline
\end{tabular}

${ }^{*}$ Highly significant at $\mathrm{p}<0.01$, *significant at $\mathrm{p}<0.05$, ns=non-significant at $\mathrm{p}=0.05, \mathrm{PH}=$ plant height, $\mathrm{TY}=$ total yield, $\mathrm{BW}=\mathrm{bulb}$ weight, $\mathrm{BD}=\mathrm{bulb}$ diameter, $\mathrm{CW}=\mathrm{clove}$ weight, $\mathrm{CN}=$ clove number, $\mathrm{DM}=$ days to maturity, idap=disease insidense days after planting,sdap=disease severity days after planting.

Table 3: Coefficients of correlation ( $r$ ) between garlic rust severity and yield and related traits of garlic.

[16] reported similar results with correlations in this disease and plant parameters. Similarly, Dill-Macky [17] reported that grain yields of some barley and winter wheat varieties were most affected by terminal stem rust severity.

\section{Conclusion}

Field experiment was conducted to study the effects of spacing on intensity and severity of garlic rust (Puccinia allii) on yield and yield components of garlic at research field of haramaya university, Ethiopia. The experiments were conducted using one garlic variety and three intra row spacing. The three intra row spacing created significantly different disease severity levels. Among intra row spacing, the lowest disease severity level was recorded on plots planted with 10 intra row spacing. Different types of intra row spacing could significantly affect bulb yield and related traits of garlic. The maximum value of yield $(7.87 \mathrm{t} / \mathrm{ha})$ was obtained from plot planted with $10 \mathrm{~cm}$ intra row spacing while, the minimize value of yield was achieved by plot planted with 20 intra row spacing. This might be due to effective use of the land resource in the populated spacing and the tolerance ability of the variety (chiro). It can thus be explained that the bulb yield per unit area depended not only on the performance of individual plants and severity of disease but also on the number of plants per unit area and also tolerance ability of a variety as confirmed in this study.

The present study revealed that, garlic rust can cause more than $51 \%$ yield loss on the crop. Hence, application of control measures to minimize the loss is justifiable in areas where it is prevalent. Optimal spacing can be used ideal methods to control the disease and to maximize bulb yield of garlic. Since this research is done in one location in a single cropping season, research works should be carried out for confirmation in similar environmental conditions in different seasons in the future.

\section{Acknowledgement}

Authors would like to thank Ethiopian ministry of education for financial support.

\section{References}

1. Rubatzky VE, Yamaguchi M (1997) World Vegetable. Principles, production and nutritive values. 2nded. Chapman and hall. International Thomson publishing New York. USA. pp 843.

2. Getachew T, Asfaw Z (2000) Achievements in shallot and garlic research. Report. No.36. Ethiopian Agricultural Research Organization, Addis Ababa. Ethiopia.

3. Azene T, Mengesha W (2015) Traditional Uses, Phytochemistry and Pharmacological Properties of Garlic (Allium Sativum) and its Biological Active Compounds. International Journal of Scientific Research in Science, Engineering and Technology 1: 142-148.
4. Pinto CMF, Mafia LA, Casali VWD, Berger RD, Cardoso AA (2000) Production components and yield losses of garlic cultivars planted at different times in a field naturally infested with Sclerotium cepivorum. International Journal of Pest Management 46: 67-72.

5. Perez ML, Salins GJ, Redondo JE (1994) Main disease on Allium species in Mexico with emphasis on white rot (Sclerotium cepivorum Berk.).p. 6-11. In Proceeding of The Fifth International Workshop on Allium white rot. Mexico.

6. Jorind (2012) Response of Garlic (Allium Sativum L.) To Intra-Row Spacing at Ajiwa Irrigation Site of Katsina State - Nigeria. Science Direct 26: 1785-1789.

7. Tesfaye T, Habtu A (1986) A review of vegetable disease in Ethiopia. In: A Review of crop protection research in Ethiopia. Tsedeke Abate (ed.) Department of Crop Protection Institute of Agricultural Research. Addis Ababa, 495-518.

8. Naruka IS, Dhaka BS (2001) Effect of row- spacing and nitrogen fertilization on growth, yield and composition of bulb in garlic (Allium sativum L.) Cultivars Journal of Spice and Aromatic Crops 10: 44-48.

9. Alam MS, Rahim MA, Bhuyan MAH, Simonand PW, Malek MA (2010) Effect of spacing on growth and yield of two lines of garlic under dry land condition. $J$ Agrofor Environ 4: 151-154.

10. Mohibullah (1991) Studies on major diseases of bulb vegetables (onion and garlic) in NWFP. Final Technical Report Agricultural Research Institute Tarnab Peshawar.

11. Darabi A, Dehghani A (2004) Effect of planting date and planting density on yield, yield components and rust disease severity. Ramhormoz Agricultural and Natural Resources Research Center of Khouzestan province, Behbehan, Iran

12. Kilgori MJ, Magaji MD, Yakubu Al (1998) Effect of plant spacing and date of planting on yield of two garlic (Allium sativum L.) Varieties Nigeria. African Journal of Biotechnology 3: 260-264.

13. Karaye AK, Yakubu Al (2005) Influence of intra-row spacing and mulching on weed growth and bulb yield of garlic (Allium sativum) in Sokoto, Nigeria. African Journal of Biotechnology 3: 260-264.

14. Abubakar SS, Murtala GB, Sani I, Jaliya MM (2008) Garlic production unde irrigation, bulletin No. 205 Agricultural Engineering Series No. 6 Produced and distributed by National Agricultural Extension and Research Liaision Services (NAERLS). Ahmadu Bello University, PMB 1067, Zaria.

15. Adejpe DI, Sebayan JAY, Chiezay UF, Miko S (2004) Yield responses of garlic (Allium satrivum L.) to Oxidiazon, date of planting and intra-row spacing under irrigation at Kadawa, Nigeria.

16. Yonas W (2010) Status of Garlic Rust (Puccinia allii L.) and Its Effects on Yield and Yield Components of Garlic in Bale Highlands, South Eastern Ethiopia. MSc. Thesis submitted to school of plant sciences, Haramaya University, Ethiopia, pp.31.

17. Dill-Macky R, Rees RG, Platz GJ (1990) Stem rust epidemics and grain yield and economic response of winter wheat to foliar fungicides. Journal of agricultural production 2: 68-73. 